\title{
A Study on Policies to Improve Wood self- sufficiency in South Korea
}

\section{Kang, Hag Mo}

Laboratory of Forest Policy, Division of Forest Environmental Sciences, Department of Agroenvironmental Sciences, Faculty of Agriculture, Kyushu University | Department of Forest

Environmental Science, Chonbuk National University

Choi, Soo Im

Laboratory of Forest Policy, Division of Forest Environmental Sciences, Department of Agroenvironmental Sciences, Faculty of Agriculture, Kyushu University | Department of Forest Resources, Sunchon National University

Sato, Norilko

Laboratory of Forest Policy, Division of Forest Environmental Sciences, Department of Agroenvironmental Sciences, Faculty of Agriculture, Kyushu Universiyt : Professor

Kim, Hyun

Laboratory of Forest Policy, Division of Forest Environmental Sciences, Department of Agroenvironmental Sciences, Faculty of Agriculture, Kyushu University | Jeollabuk-do Forest Environment Research Institute

https://doi.org/10.5109/1801787

出版情報：九州大学大学院農学研究院紀要. 62 (1)，pp.217-223，2017-02-24. Faculty of Agriculture, Kyushu University

バージョン :

権利関係 : 


\title{
A Study on Policies to Improve Wood self-sufficiency in South Korea
}

\author{
Hag Mo KANG ${ }^{1}$, Soo Im $\mathrm{CHOI}^{2 *}$, Noriko SATO and Hyun KIM ${ }^{3}$ \\ Laboratory of Forest Policy, Division of Forest Environmental Sciences, \\ Department of Agro-environmental Sciences, Faculty of Agriculture, \\ Kyushu University, Fukuoka 812-8581, Japan \\ (Received October 24, 2016 and accepted November 4, 2016)
}

\begin{abstract}
Although the wood self-sufficiency in South Korea up to 2007 was not even 10\%, it has recently begun to increase gradually, reaching $16.7 \%$ in 2014 . This improvement in wood self-sufficiency is the result of various forestry policies to expand the gradually maturing supply of domestic wood. Broadly, there were two types of policies to improve wood self-sufficiency, established as part of the Fifth National Forest Plan (2008-2017). The first are policies to ensure a stable supply of domestic timber, such as properly timed felling of forest trees that have reached cutting age and species conversion in forests of low value. Such policies will be able to supply an additional $600,000 \mathrm{~m}^{3}$ of domestic timber per year. The second type of policy is based on the time during which wood can be sold for the best price, in order to increase the income of forest owners by relaxation of the standard cutting ages. The standard cutting age for oak trees has been shortened from 50 to 25 years, and the standard cutting age for larch trees (Larix leptolepis) has been relaxed from 40 to 30 years. Relaxing the standard cutting ages will increase the timber harvest, leading to a growth in domestic timber production of $265,000 \mathrm{~m}^{3}$ per year. As a result, wood self-sufficiency is forecasted to reach $21 \%$ by 2017 .
\end{abstract}

Key words: wood self-sufficiency, forest policies, domestic timber, relaxation of standard cutting ages

\section{INTRODUCTION}

Although forests account for approximately $64 \%$ of the total land area of South Korea, South Korea is a major importer of timber, relying on imports for the majority of the domestic timber demand. This is because of the exploitation of forests during the Japanese Occupation and the destruction of most forest resources in the Korean War, with projects to restore forests and recover domestic forest resources only starting in the late 1960s. As a result, most trees are still young and there is not enough supply to satisfy the demand for timber. The excess timber demand has also been furthered by the country's development into a government-led trade country, and a surge in timber demand due to rapid economic growth (Korea Rural Economic Institute [KREI], 1993).

This excess timber demand is expected to continue in the future. This is the result of the development and expansion of the forest industry being planned to match the scale of economic growth, population growth, and expansion of the construction market, even though domestic timber resources are not yet mature enough for use (Korea Forest Research Institute [KFRI], 2007).

Nevertheless, with the gradual large-scale maturation of forest resources since the 1970s, these trees are approaching cutting age, which will lead to an increase of approximately $30 \%$ in the proportion of resources of

\footnotetext{
1 Department of Forest Environmental Science, Chonbuk National University, Chonju 54896, South Korea

2 Department of Forest Resources, Sunchon National University, Suncheon 57922, South Korea

3 Jeollabuk-do Forest Environment Research Institute, Jinan 55454 , South Korea

* Corresponding author (E-mail: sooim@sunchon.ac.kr)
}

at least age-class five (41 years or more), meaning that the potential domestic timber supply is growing incrementally (Korea Forest Service [KFS], 2014a). Consequently, the supply of domestic timber has shown a large 3.4-fold increase from $1,530,000 \mathrm{~m}^{3}$ in 2001 to $5,180,000 \mathrm{~m}^{3}$ in 2014 . In the same period, wood self-sufficiency has also improved considerably, with the amount of domestic timber as a percentage of total timber supply (imported timber and domestic timber) increasing by 17-58\% (KFS, 2013a; 2014b; 2015a). Specifically, wood self-sufficiency has improved greatly, from 5.9\% in 2001 to $8.8 \%$ in $2005,13.5 \%$ in 2010 , and reaching $16.7 \%$ in 2014 (KFS, 2015b).

The improvement in wood self-sufficiency is the result of various forestry policies implemented as a part of the Fifth National Forest Plan (2008-2017) and President Geun-Hye Park's promise in her election manifesto to achieve a wood self-sufficiency of $21 \%$ by 2017 , including forest management and species conversion projects (KFS, 2013b). These plans are forecasted to increase the production and supply of domestic timber as domestic forest resources gradually mature.

This study aims to analyze the types of forest policies that have recently improved wood self-sufficiency, as well as how much of an effect these policies have on wood self-sufficiency.

\section{MATERIALS AND METHODS}

The analysis of policies to improve wood self-sufficiency in South Korea requires data from the KFS on the policies and the main plans for timber resources. In particular, considering that the major increase in wood selfsufficiency has occurred in the latter stages of the Fifth National Forest Plan (2008-2017), we analyzed which 
policies were implemented based on policy and main planning data from the KFS after the late 2000s. We also examined how much of an effect these plans and policies actually had on improving wood self-sufficiency.

\section{RESULTS AND DISCUSSIONS}

\section{Trends in Timber Supply and Demand}

Overview of timber supply and demand

Looking at South Korea's timber supply in terms of domestic and imported timber, the current volume of domestic timber, as of 2014 , is only $5,180,000 \mathrm{~m}^{3}$, while the volume of imported timber is far greater. Although the supply of domestic timber was a mere $1,100,000 \mathrm{~m}^{3}$ up to 1997, it began to gradually increase after this, reaching 2,300,000 $\mathrm{m}^{3}$ in 2005 and 5,180,000 $\mathrm{m}^{3}$ in 2014 . Wood self-sufficiency, which is the percentage of total timber supply accounted for by domestic timber, was only $4-5 \%$ in 1998, but increased together with the domestic timber supply to $5.7 \%$ in $2000,8.8 \%$ in 2005 , $13.5 \%$ in 2010, and its highest ever recorded value of 17.4\% in 2013 (Kang, 2014; KFS, 2015b). Nevertheless, despite the increase in domestic timber production and wood self-sufficiency through the efforts of the KFS to increase the use of forest resources, the majority of the timber produced consists of small-diameter timber, which is less useful for industrial purposes (KFS, 2014a).

Meanwhile, the volume of imported timber was $20,600,000 \mathrm{~m}^{3}$ in $1990,24,270,000 \mathrm{~m}^{3}$ in 1995, and a record $27,440,000 \mathrm{~m}^{3}$ in 2002 . Since then, with the decrease in round wood imports, the volume of imported timber has decreased to $23,890,000 \mathrm{~m}^{3}$ in 2010 and $23,310,000 \mathrm{~m}^{3}$ in 2012. Looking separately at timber imports in terms of round wood and wood products, the ratio of round wood to wood products in 1990 was 40\% to $60 \%$. Since then, the proportion of wood products has increased to $74 \%$ in 2000 , and $80 \%$ in 2010 . As of 2014, the current proportion of imported timber accounted for by round wood is $14 \%$, and the proportion accounted for by wood products is $84 \%$ (Table 1 ).

\section{Trends in domestic timber production}

Looking at trends in the production of domestic round wood, which is directly related to improvements in wood self-sufficiency, production was no more than $1,100,000 \mathrm{~m}^{3}$ in $1990 \mathrm{~s}$. However, since the late $1990 \mathrm{~s}$, production has gradually increased, maintaining a level of $1,700,000 \mathrm{~m}^{3}$ by 2003 . After that, following the ratification of the Kyoto Protocol, forest management projects were actively pursued to expand forest sinks as a countermeasure to global warming. This resulted in further increases in domestic round wood production to $2,030,000 \mathrm{~m}^{3}$ in $2004,3,710,000 \mathrm{~m}^{3}$ in 2010 , and a record $5,200,000 \mathrm{~m}^{3}$ in 2014 (a 4.7-fold increase compared to 1990) (Table 2).

Looking at domestic timber production by use, of the $5,200,000 \mathrm{~m}^{3}$ total production in 2014, the majority was used for lumber, at 4,620,000 m3, followed by $9,100,000 \mathrm{~m}^{3}$ for pulp wood, and 7,000 $\mathrm{m}^{3}$ for pit prop. In particular, lumber production, which mostly consists of needle-leaf trees, has increased from $220,000 \mathrm{~m}^{3}$ in 1990 to $930,000 \mathrm{~m}^{3}$ in 2000 , and $2,790,000 \mathrm{~m}^{3}$ in 2010 , reaching a record 4,260,000 $\mathrm{m}^{3}$ in 2014 (an approximately 20fold increase compared to 1990).

Table 1. Trends of Timber Supply and Demand

\begin{tabular}{|c|c|c|c|c|c|c|}
\hline \multirow{2}{*}{ Year } & \multirow{2}{*}{ Total } & \multicolumn{3}{|c|}{$\log$} & \multirow{2}{*}{$\begin{array}{c}\text { Timber Product } \\
\text { Import }\end{array}$} & \multirow{2}{*}{$\begin{array}{l}\text { Self-Sufficiency Rate } \\
\text { (\%) }\end{array}$} \\
\hline & & Total & Domestic & Import & & \\
\hline 1990 & 21,746 & 9,423 & 1,138 & 8,285 & 12,323 & 5.2 \\
\hline 1995 & 25,325 & 9,284 & 1,055 & 8,229 & 16,041 & 4.2 \\
\hline 2000 & 27,970 & 8,327 & 1,592 & 6,735 & 19,643 & 5.7 \\
\hline 2001 & 26,243 & 8,836 & 1,533 & 7,303 & 17,407 & 5.9 \\
\hline 2002 & 29,047 & 9,312 & 1,605 & 7,707 & 19,735 & 5.5 \\
\hline 2003 & 27,389 & 8,727 & 1,740 & 6,987 & 18,662 & 6.4 \\
\hline 2004 & 27,211 & 8,619 & 2,037 & 6,582 & 18,592 & 7.5 \\
\hline 2005 & 26,719 & 8,372 & 2,350 & 6,022 & 18,347 & 8.8 \\
\hline 2006 & 26,623 & 8,809 & 2,444 & 6,365 & 17,814 & 9.2 \\
\hline 2007 & 27,347 & 9,013 & 2,680 & 6,333 & 18,334 & 9.8 \\
\hline 2008 & 26,752 & 7,969 & 2,702 & 5,267 & 18,783 & 10.1 \\
\hline 2009 & 26,607 & 8,190 & 3,176 & 5,014 & 18,417 & 11.9 \\
\hline 2010 & 27,612 & 7,942 & 3,715 & 4,227 & 19,670 & 13.5 \\
\hline 2011 & 27,608 & 8,240 & 4,210 & 4,030 & 19,368 & 15.2 \\
\hline 2012 & 27,819 & 8,192 & 4,506 & 3,686 & 19,627 & 16.2 \\
\hline 2013 & 28,151 & 8,654 & 4,897 & 3,757 & 19,497 & 17.4 \\
\hline 2014 & 31,005 & 8,855 & 5,179 & 3,676 & 22,150 & 16.7 \\
\hline
\end{tabular}

Source: Korea Forest Service. 2015 Statistical Yearbook of Forestry 
Table 2. Trends of Log Supply and Demand

\begin{tabular}{ccccc}
\hline Year & Total & Pit Prop & Pulp Wood & $\begin{array}{c}\text { General } \\
\text { Product }\end{array}$ \\
\hline 1990 & 1,138 & 512 & 410 & 216 \\
1995 & 1,055 & 139 & 405 & 511 \\
2000 & 1,592 & 112 & 552 & 928 \\
2001 & 1,533 & 140 & 366 & 1,027 \\
2002 & 1,605 & 58 & 373 & 1,174 \\
2003 & 1,740 & 63 & 449 & 1,228 \\
2004 & 2,037 & 52 & 478 & 1,497 \\
2005 & 2,350 & 55 & 400 & 1,895 \\
2006 & 2,444 & 47 & 522 & 1,875 \\
2007 & 2,680 & 45 & 667 & 1,968 \\
2008 & 2,702 & 45 & 838 & 1,819 \\
2009 & 3,176 & 39 & 797 & 2,340 \\
2010 & 3,715 & 29 & 892 & 2,794 \\
2011 & 4,210 & 32 & 1,022 & 3,156 \\
2012 & 4,506 & 18 & 1,033 & 3,455 \\
2013 & 4,897 & 7 & 980 & 3,910 \\
2014 & 5,179 & 7 & 910 & 4,262 \\
\hline
\end{tabular}

Source: Korea Forest Service. 2014 Statistical Yearbook of Forestry

\section{Major Policies to Improve Wood self-sufficiency}

Major forest policies that recently have been driving the improvement in wood self-sufficiency in South Korea can be broadly divided into two types. The first type pertains to the "expansion of a stable supply of domestic timber," with examples such as the "Comprehensive Plan to Improve the Timber Industry (2012-2016)" and the "Comprehensive Plan for Sustainable Timber Use (2015-2019)," established as a part of the core tasks (Measures for Advancement of the Timber Industry) in the Fifth National Forest Plan (2008-2017). The second type pertains to the "relaxation of standard cutting ages," implemented as a part of economic vitalization and relaxation of regulations with the start of a new government in 2013. Therefore, in this section we aim to analyze in detail the association between these two types of forest policy with wood selfsufficiency.

Policies to expand the stable supply of domestic timber

The South Korean government legislated the "Act on the Sustainable Use of Timbers" in order to provide systematic support for the "Measures for the Advancement of the Timber Industry," which was one of the core tasks of the Fifth National Forest Plan (2008-2017). As a part of the implementations, the "Comprehensive Plan to Improve the Timber Industry (2012-2016)" was established in November 2011, and the "Comprehensive Plan for Sustainable Timber Use (2015-2019)" was established in November 2014 (KFS, 2011; 2014a). The main aim of these plans was to achieve at least $20 \%$ wood self-sufficiency by 2016. One precondition for setting this goal was that the gradually maturing domestic forest resources would be usable as timber. Also, as new generations of domestic timber are introduced in the future, this expansion of the stable supply of domestic timber could lead to further effects, such as improving the competitiveness of the domestic lumber industry, stimulating use of wood products, and stimulating construction based on the development of the timber industry.

There is currently an uneven distribution of ageclasses among South Korean forest resources, which is disadvantageous for the future expansion of carbon absorption and sustainable forest management. Specifically, while $66 \%$ of forest-tree stocks are ageclass four (31-40 years) or five (41-50 years), a decrease in the formation of new forests means that only $3.3 \%$ of forest trees are age-class two or less ( $\leq 20$ years) (KFS, 2014a). In addition, the age-class structure needs long-term stimulation through early species conversion and properly timed harvesting of trees in forests of low economic value, or of those that have reached cutting age. Efficient collection of round wood from tree harvesting and forest management projects is difficult, and the resources are mostly used for low-value, low-quality timber. Round wood and byproducts totaled $7,640,000 \mathrm{~m}^{3}$ in 2010, of which $3,720,000 \mathrm{~m}^{3}$ - $49 \%$ - was used and the remainder was left neglected in forestland. Meanwhile, approximately $87 \%$ of the collected round wood is small-diameter timber of $18 \mathrm{~cm}$ or less, which is used to supply pulp and wood panels. The introduction of the Renewable Portfolio Standard (RPS) and other new systems for carbon reduction is leading to increased competition for raw ingredients between energy companies and the timber industry (e.g. wood panel companies), such as in the case of cogeneration (KFS, 2011; 2014a).

In this environment, if the stable supply of domestic timber is not expanded, it seems impossible to achieve the goals of improving the domestic timber industry and securing at least $20 \%$ wood self-sufficiency by 2016. As a result, four types of strategies have been established to expand the stable supply of domestic timber: acquiring new land for forest production, developing a more sustainable age-class system, improving systems of forest tree production and collection, and improving resourcecycling systems for the recycling of timber.

As a part of securing new lands for timber production, short rotation coppices (SRC) were formed using non-forest land, such as reclaimed land and riverside land, from 20 ha in 2012 up to 2,000 ha in 2016, in order to expand the supply of timber for energy purposes. In addition, by 2020 there will be an expansion up to 100,000 ha in the formation of bio-cycling forests and industrial-timber forests on non-arable land and other fallow land to supply low-grade and small-diameter timber (Table 3). In particular, there are plans to pursue a stable supply of industrial timber for wood pellets and lumber through expansion of bio-cycling forests.

In order to develop a more sustainable age-class structure, the felling volume of cutting-age trees has been expanded from $1,060,000 \mathrm{~m}^{3}$ to $2,000,000 \mathrm{~m}^{3}$ in 2016 , resulting in an additional annual supply of approxi- 
Table 3. Plans for the formation of bio-cycling forests

\begin{tabular}{cccccccc}
\hline Type & Total & Up to 2009 & 2010 & 2011 & 2012 & 2013 & $2014-2020$ \\
\hline Total & 100,116 & 6,116 & 6,000 & 8,000 & 10,000 & 12,000 & 58,000 \\
Private forests & 89,457 & 5,457 & 5,000 & 7,000 & 9,000 & 11,000 & 52,000 \\
National forests & 10,659 & 659 & 1,000 & 1,000 & 1,000 & 1,000 & 6,000 \\
\hline
\end{tabular}

Source: Korea Forest Service. 2013b Fifth National Forest Plan (amended) 2013-2017

mately $150,000 \mathrm{~m}^{3}$ of round wood. Moreover, there are plans to supply an additional $600,000 \mathrm{~m}^{3}$ of timber per year by 2020 through species conversion of low-value forests. In support of these plans and looking at the records of permits to fell trees for domestic timber, the total volume has increased considerably from $4,220,000 \mathrm{~m}^{3}$ in 2010 to $8,760,000 \mathrm{~m}^{3}$ in 2014 . Reasons for this include the final clearing of maturing domestic forest resources, as well as forest tending, thinning for profit, species conversion, and felling of damaged trees, as a part of projects to improve the age-class structure (Figure 1).

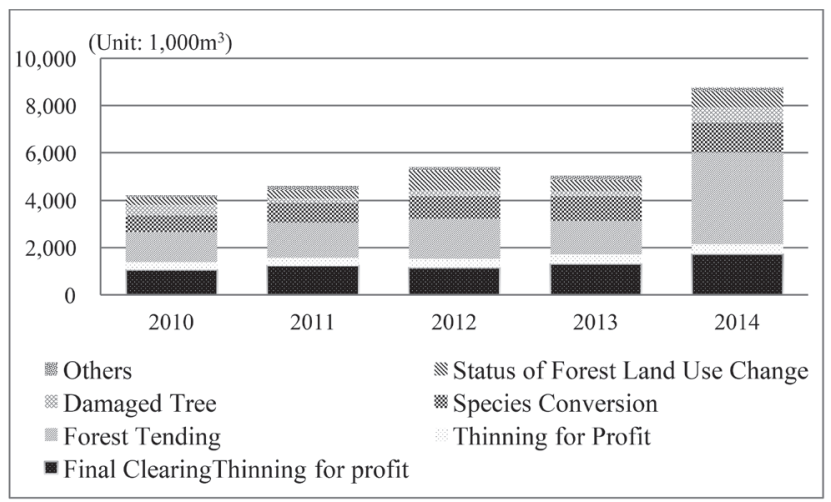

Notice: Since these are records of permits granted for felling trees, they may differ from the actual whole timber production levels.

Source: Korea Forest Service. 2015 Statistical Yearbook of Forestry

Fig. 1. Trends Records of permission to fell trees for domestic timber.

In order to improve systems for tree production and collection, although it indicates a reduced economy, investing manpower in cut-to-length logging should be able to reduce the damage to forests caused by wholetree or tree-length logging and improve the economics of product collection. This should enable the collection and usage of round wood from felling and forest management to expand from $49 \%$ in 2012 to $60 \%$ in 2016 , as well as increase the current volume of collected and utilized products from the current level of $3,720,000 \mathrm{~m}^{3}$ up to $4,500,000 \mathrm{~m}^{3}$.

In order to improve resource-cycling systems to recycle timber, after excluding by-products with no impact on the environment, forest by-products have been classified in the "Act on the Promotion of the Development, Use, and Diffusion of New and Renewable Energy" as bio-energy to promote recycling of waste timber. In addition, the weights for the renewable energy certificate (REC) of woody biomass will be adjusted to promote efficient use of timber resources through the construction of a resource-cycling system of timber recycling.

\section{Policies to relax standard cutting ages}

According to the long-term forest-resource supply and demand forecasts of the KFS, the current age-class structure, in which $67 \%$ of trees are age-class three or four (21-40years), is expected to lead to a structure where over $70 \%$ of trees are age-class seven or higher (>60 years) by 2050 (KFS, 2014b). Meanwhile, the level of sustainable timber production is forecasted to gradually increase due to the increase in forest stocks (Table 4). In other words, although the appropriate time for production is approaching due to the continual increase in forest stocks, the lack of changes to felling systems is expected to lead to a more severe imbalance in the ageclass structure.

Due to this situation, forest owners, timber producers, and members of the forestry industry repeatedly petitioned the government concerning the illogical standard cutting ages (the age at which a tree can be felled and used), which were unsuited to the state of the market. Thus in 2014, the government accepted the need for a relaxation of standard cutting ages, including tasks such as the normalization and relaxation of regulations. In particular, for private forests, a relaxation of standard cutting ages should account for the demand in the timber market at the current maximum cutting age for timber, which is required for the protection of private

Table 4. Long-term forecasts for forest resources

\begin{tabular}{ccccc}
\hline Type & Unit & 2010 & 2030 & 2050 \\
\hline Felling volume/growth volume in land for timber production & $\%$ & 24 & 39 & 94 \\
Total forest stocks & $1,000,000 \mathrm{~m}^{3}$ & 800 & 1227 & 1443 \\
Forest stock/ha & $\mathrm{m}^{3}$ & 125 & 194 & 225 \\
\hline
\end{tabular}

Source: Korea Forest Research Institute. 2007 Trends and Long-term Forecasts in the Field of Forestry 
property and an increase in income for forest owners.

From the government's perspective, relaxation of the standard cutting ages will lead to an increase in felling volume, making it possible to achieve $21 \%$ wood selfsufficiency by 2017, as promised in President Geun-Hye Park's election manifesto, and it will resolve the petitions that have continually been raised by the forestry field up to this point.

Cutting age refers the age at which a tree should be cut, in order to best achieve the aims of forest management according to the Forest Management Plan. In South Korea, the standard-cutting-age system was first introduced for major tree species in 1965, during the compilation of the Forest Management Plan. Since then, the focus, over seven rounds of policy formation, has been on forest protection and cultivation, and so, although there are differences for individual species, the standard cutting ages have generally increased.

However in September 2014, the KFS amended the "Enforcement Ordinance for the Forest Resources Creation and Management Act" to relax criteria for the cutting age of trees (standard cutting ages). The amendments to the standard cutting ages distinguished between private and national forests.

In order to protect private property and to drive forest-owner income upwards, the existing maximum cutting ages for timber harvesting were revised for private forests to suit the demand in the timber market. Specifically, the criteria were based on the age at which timber could fetch the best market price. For oak trees, the age at which they could be cut for Lentinula edodes cultivation was relaxed from 50 to 25 years. Up to now, Lentinula edodes cultivation had suffered difficulties due to the inadequate supply of oak trees, but this relaxation of the standard cutting age is expected to enable a stable supply of oak trees for shiitake cultivation. The standard cutting age for larch trees has been reduced from 40 to 30 years, based on the $20 \mathrm{~cm}$-size that is suitable for lumber (Table 5).
For national forests, although the maximum cutting age for timber harvesting will be improved in order to expand production of large-diameter timber and the supply of domestic timber, the plan is to gradually relax the standards, while taking into account the value of natural forests to the public.

Meanwhile, estimates of the increase in felling volume, when standard cutting ages are shorten, are as follows. In order to estimate the felling volume, the percentage increase can be calculated by first deriving the potential felling volume after changing the standard cutting ages, then estimating the anticipated actual felling volume (anticipated felling volume taking into account to average annual felling rate), and finally comparing this value to the felling volume prior to relaxation of the standard cutting ages. According to this method, the estimated increase in felling volume over the next 10 years, after relaxation of standard cutting ages, is approximately $2,650,000 \mathrm{~m}^{3}$ (with an annual average increase in felling volume of $26.5 \%)$. When analyzed by tree species, Quercus spp. (1,060,000 m³), Pinus densiflora $\left(930,000 \mathrm{~m}^{3}\right)$, and other broadleaf trees $\left(390,000 \mathrm{~m}^{3}\right)$ accounted for $89.9 \%$ of the total increase (Table 6) (KFS, 2014b).

Looking at the actual effect on production of domestic timber after relaxation of standard cutting ages on September 25, 2014, domestic timber production (based on collected volume) in the third quarter of 2015 was $900,000 \mathrm{~m}^{3}$, which represents a $14.7 \%$ increase compared to the same period of the previous year $\left(791,000 \mathrm{~m}^{3}\right)$. Of this production, harvest felling accounted for $400,000 \mathrm{~m}^{3}$, which was a $119.6 \%$ increase compared to the same period of the previous year. This results from an increase in harvest felling in private and national forests, with the expectation of increased profits following the relaxation of standard cutting ages (Table 7). In the future, the relaxation of standard cutting ages is expected to cause an increase in harvest felling for profit.

Table 5. Changes of standard cutting ages by species

\begin{tabular}{ccccc}
\hline & \multicolumn{2}{c}{ Current state } & \multicolumn{2}{c}{ Revisions } \\
\cline { 2 - 5 } Species & National forests & $\begin{array}{c}\text { Public/ } \\
\text { private forests }\end{array}$ & National forests & $\begin{array}{c}\text { Public/ } \\
\text { private forests }\end{array}$ \\
\hline Pinus densiflora & 70 & 50 & 60 & 40 \\
Pinus koraiensis & 70 & 60 & 60 & 50 \\
Pinus rigida Mill. & 35 & 25 & 30 & 25 \\
Larix leptolepis & 60 & 40 & 50 & 30 \\
Cryptomeria japonica & 60 & 40 & 50 & 30 \\
Chamaecyparis obtusa & 70 & 50 & 60 & 40 \\
Other needle-leaf trees (new) & - & - & 60 & 40 \\
Quercus spp. & 70 & 50 & 60 & 25 \\
Populus spp. & 15 & 15 & & 3 \\
Other broadleaf trees (new) & - & - & 60 & 40 \\
\hline
\end{tabular}

Source: Ministry of Government Legislation. 2015 Enforcement Ordinance for the Forest Resources Creation and Management Act 
Table 6. Estimated increase in felling volume following relaxation of standard cutting ages

(Units: $1,000 \mathrm{~m}^{3}$ )

\begin{tabular}{|c|c|c|c|c|c|c|c|}
\hline \multirow{2}{*}{ Species } & \multicolumn{3}{|c|}{ Before relaxation of standard cutting ages } & \multicolumn{2}{|c|}{$\begin{array}{l}\text { After relaxation of standard } \\
\text { cutting ages }\end{array}$} & \multirow{2}{*}{$\begin{array}{c}\text { Additional felling } \\
\text { volume } \\
\mathrm{D}=(\mathrm{C}-\mathrm{B})\end{array}$} & \multirow{2}{*}{$\begin{array}{c}\text { Percentage } \\
\text { increase in felling } \\
\text { volume (D/A) }\end{array}$} \\
\hline & $\begin{array}{c}\text { Potential } \\
\text { felling volume }\end{array}$ & $\begin{array}{l}\text { Felling volume } \\
\text { (A) }\end{array}$ & $\begin{array}{l}\text { Final clearing } \\
\text { volume (B) }\end{array}$ & $\begin{array}{c}\text { Potential } \\
\text { felling volume }\end{array}$ & $\begin{array}{l}\text { Final clearing } \\
\text { volume }(\mathrm{C})\end{array}$ & & \\
\hline Total & 108052 & 9992 & 1326 & 324334 & 3980 & 2654 & $26.5 \%$ \\
\hline Pinus densiflora & 24211 & 2239 & 297 & 99903 & 1226 & 929 & $41.5 \%$ \\
\hline Pinus koraiensis & 744 & 69 & 9 & 1488 & 18 & 9 & $13.3 \%$ \\
\hline Pinus rigida Mill. & 27687 & 2560 & 340 & 30315 & 372 & 32 & $1.3 \%$ \\
\hline Larix leptolepis & 7579 & 701 & 93 & 21988 & 270 & 177 & $25.2 \%$ \\
\hline $\begin{array}{l}\text { Cryptomeria } \\
\text { japonica }\end{array}$ & 862 & 80 & 11 & 2106 & 26 & 15 & $19.1 \%$ \\
\hline $\begin{array}{l}\text { Chamaecyparis } \\
\text { obtuse }\end{array}$ & 893 & 83 & 11 & 3691 & 45 & 34 & $41.5 \%$ \\
\hline Quercus spp. & 24736 & 2288 & 304 & 111430 & 1367 & 1064 & $46.5 \%$ \\
\hline Populus spp. & 383 & 35 & 5 & 429 & 5 & 1 & $1.6 \%$ \\
\hline $\begin{array}{l}\text { Other broadleaf } \\
\text { trees (new) }\end{array}$ & 20956 & 1938 & 257 & 52985 & 650 & 393 & $20.3 \%$ \\
\hline
\end{tabular}

Source: Korea Forest Service. 2014b The KFS relaxes cutting age criteria for the first time in 49 years. KFS press release (24 $4^{\text {th }}$ Sep. 2014)

Table 7. The state of domestic timber production (based on collected volume)

\begin{tabular}{|c|c|c|c|c|c|c|c|c|}
\hline \multirow{2}{*}{ Type } & \multicolumn{4}{|c|}{2014} & \multicolumn{3}{|c|}{2015} & \multirow{2}{*}{$\begin{array}{l}\text { Compared to same } \\
\text { quarter of the } \\
\text { previous year }\end{array}$} \\
\hline & $1 / 4$ & $2 / 4$ & $3 / 4$ & $4 / 4$ & $1 / 4$ & $2 / 4$ & $3 / 4$ & \\
\hline Total & 1156 & 923 & 787 & 2436 & 1359 & 831 & 903 & 14.7 \\
\hline Harvest felling & 484 & 135 & 184 & 896 & 775 & 308 & 404 & 119.6 \\
\hline Thinning for profit & 82 & 94 & 63 & 118 & 41 & 70 & 58 & 11.1 \\
\hline Forest tending & 110 & 252 & 169 & 467 & 36 & 138 & 117 & -30.8 \\
\hline Species conversion & 298 & 176 & 191 & 559 & 285 & 111 & 117 & -38.7 \\
\hline Damaged Tree & 66 & 51 & 13 & 165 & 128 & 61 & 98 & 653.8 \\
\hline Status co Forest land & 81 & 188 & 162 & 173 & 73 & 126 & 95 & -41.4 \\
\hline Other & 37 & 27 & 6 & 58 & 21 & 17 & 14 & 133.3 \\
\hline
\end{tabular}

Source: Korea Forest Research Institute. 2015 Economic Trends in Forestry, Fall 2015

\section{CONCLUSION}

South Korea is a timber-importing country, dependent on imports for the majority of the domestic timber demand, even though approximately $64 \%$ of the total land area is forest. Since the country's economic development began after its forest resources had been destroyed by the Korean War, it was inevitable that Korea became dependent on imported timber for the majority of its timber supply. However, wood self-sufficiency has been increasing recently. In particular, wood self-sufficiency was less than $10 \%$ up to 2007 , but has increased to $16.7 \%$ in 2014, since the implementation of the Fifth National Forest Plan (2008-2017). Although improvements in wood self-sufficiency are affected considerably by the domestic economy and the cost of imported timber, they have also been the result of various forest policies seeking to expand the supply of gradually maturing, domestic-timber stocks. Hence, this study analyzed the forest policies that recently have improved wood self-sufficiency in South Korea.
The major policies driving the recent improvement in wood self-sufficiency in South Korea are "expansion of the stable supply of domestic timber" and "relaxation of standard cutting ages," which were established in the Fifth National Forest Plan (2008-2017). Policies to expand the stable supply of domestic timber aimed to achieve wood self-sufficiency of at least 20\% by 2016 . One precondition for setting this goal was that domestic forest resources would become usable for timber as they gradually matured. Four types of strategies were established and are currently being implemented to expand the stable supply of domestic timber: acquisition of new land for timber production by 2019, development of a more stable age-class structure, improvement of the system for tree production and collection, and improvement of resource-cycling systems for recycling of timber. Of these, developing a more sustainable age-class structure has improved wood self-sufficiency by supplying an additional $600,000 \mathrm{~m}^{3}$ of domestic timber per year, through felling trees of cutting age at the appropriate time and species conversion of low-quality forests. 
Meanwhile, policies to relax standard cutting ages were implemented as a part of economic vitalization and the relaxation of regulations in 2014. In particular, relaxation of standard cutting ages increased the felling volume and so, was an important step given that President Geun-Hye Park's declared in her election manifesto that 21\% wood self-sufficiency could be achieved by 2017. Relaxation of standard cutting ages was implemented for the first time in 49 years, and in private forests, cutting ages were set based on the time at which timber could achieve the optimum price on the market to increase the income of forest owners. The age at which oak trees can be felled for shiitake cultivation was relaxed from 50 to 25 years. For Larix leptolepis, the cutting age was reduced from 40 to 30 years, based on the $20 \mathrm{~cm}$-size suited for use as lumber. This relaxation of standard cutting ages is expected to cause an increase in harvest felling, allowing domestic timber production to increase by $270,000 \mathrm{~m}^{3}$ per year and making it possible to achieve 21\% wood self-sufficiency by 2017 .

Domestic timber production is increasing due to recent policies to increase wood self-sufficiency. Nevertheless, most of the round wood currently being produced is small-diameter or thinning timber, used as a low-grade material, such as wood panels, pulp, and biomass. Domestic timber production is forecasted to expand gradually in the future, with the development of a more sustainable forest structure and the construction of forest management fundamentals. Therefore, diverse, practical measures will need to be established to construct a sustainable timber supply system.

On the other hand, investigating the relationship between the income increase effect for mountain villages though policies to raise self-sufficiency rates for timber and environmental service functions of forests presents scope for empirical study.

\section{ACKNOWLEDGEMENTS}

This research was carried out under a collaborative research project, "Policy development for improvement of wood self-sufficiency ratio and the socio-economic effects on mountainous areas in East Asia" with financial support from JSPS ((B) 25292090).

\section{REFERENCES}

Hag Mo Kang, Soo Im Choi and Noriko Sato. 2015 Study on Trends and Characteristics of Timber Supply and Demand in Korea. Journal of Faculty of Agriculture Kyushu University, 60 (2): 543-552

Korea Forest Service [KFS]. 2011 Comprehensive Plan to Improve the Timber Industry (2012-2016)

Korea Forest Service [KFS]. 2013a Outlook of Timber Supply and Demand for 2013

Korea Forest Service [KFS]. 2013b Fifth National Forest Plan (amended) 2013-2017

Korea Forest Service [KFS]. 2014a Comprehensive Plan for the Sustainable Use of Timber (2015-2019)

Korea Forest Service [KFS]. 2014b The KFS relaxes cutting age criteria for the first time in 49 years. KFS press release (24 $4^{\text {th }}$ Sep. 2014)

Korea Forest Service [KFS]. 2014c Plans for Timber Supply and Demand in 2014

Korea Forest Service [KFS]. 2015a 2015 Statistical Yearbook of Forestry

Korea Forest Service [KFS]. 2015b Plans for Timber Supply and Demand in 2015

Korea Forest Research Institute [KFRI]. 2007 Trends and Longterm Forecasts in the Field of Forestry

Korea Forest Research Institute [KFRI]. 2015 Economic Trends in Forestry, Fall 2015

Korea Rural Economic Institute [KREI]. 1993 Changes in the Global Timber Market and Plans for Stable Acquisition of Timber

Korea Rural Economic Institute [KREI]. 2008 Modelling Supply-demand Structure and Outlook of Korean Timber

Korea Rural Economic Institute [KREI]. 2011 Policy Issues on Wood Demand and Supply to Tackle Climate Change 